\title{
LANDSCAPE-LEVEL PATTERNS OF MERCURY CONTAMINATION OF FISH IN NORTH TEXAS, USA
}

\author{
Ray W. Drenner, ${ }^{*} \dagger$ Matthew M. Chumchal,$\dagger$ Stephen P. Wente,$\ddagger$ Mandy McGuire,$\oint$ and S. Matthew Drenner $\dagger$ \\ $\dagger$ Biology Department, Texas Christian University, Fort Worth, Texas, USA \\ $\ddagger$ Lake Hart Research, Reston, Virginia, USA \\ $\S$ Environmental Science Program, Texas Christian University, Fort Worth, Texas, USA
}

(Submitted 10 February 2011; Returned for Revision 18 March 2011; Accepted 27 April 2011)

\begin{abstract}
Mercury ( $\mathrm{Hg})$ is a toxic metal that is found in aquatic food webs and is hazardous to humans. An emerging conceptual model predicts that the areas of the landscape that have the potential to contain food webs with elevated concentrations of $\mathrm{Hg}$ are those that receive high amounts of $\mathrm{Hg}$ and sulfate deposition and have high coverage of forests and wetlands and low coverage of agriculture. The objective of the present study was to test this conceptual model using concentrations of $\mathrm{Hg}$ in largemouth bass (Micropterus salmoides) from 145 reservoirs in four ecoregions of North Texas. The highest level of $\mathrm{Hg}$ contamination in fish was in the South Central Plains, the ecoregion that receives the highest levels of $\mathrm{Hg}$ and sulfate deposition and contains extensive forest and wetland habitat and little agriculture. The present study has important implications for other areas of the United States, because the South Central Plains extend into parts of Oklahoma, Louisiana, and Arkansas, covering a total area of 152,132 $\mathrm{km}^{2}$ of the southern United States. Environ. Toxicol. Chem. 2011;30:2041-2045. (C) 2011 SETAC
\end{abstract}

Keywords-Mercury Atmospheric deposition Ecoregion Largemouth bass Land cover

\section{INTRODUCTION}

Because of its extreme toxicity and its widespread presence in aquatic food webs, methyl mercury $(\mathrm{MeHg})$ poses a threat to human health. The primary pathway of MeHg into humans is through the consumption of $\mathrm{MeHg}$-contaminated fish [1,2]. Human fetuses are particularly sensitive to $\mathrm{MeHg}$, and prenatal exposure to $\mathrm{MeHg}$ can cause developmental and cognitive problems [1,2]. Warning the public about exposure to harmful levels of mercury $(\mathrm{Hg})$ depends on identification of water bodies with elevated concentrations of $\mathrm{Hg}$ in fish, followed by the issuance of fish consumption advisories [3]. Because it is impractical to sample $\mathrm{Hg}$ in all water bodies where fishing may occur, the ability to predict which areas of the landscape are likely to contain water bodies with high fish $\mathrm{Hg}$ burdens is critical.

An emerging conceptual model predicts that areas of the landscape with elevated $\mathrm{Hg}$ and sulfate deposition, high coverage of forests and wetlands, and low coverage of agriculture are most likely to contain food webs with elevated $\mathrm{Hg}$ concentrations $[4,5]$. Atmospheric deposition is the primary source of $\mathrm{Hg}$ to aquatic systems [6]. Mercury contamination of fish has been correlated with deposition of atmospheric $\mathrm{Hg}$ [7], but sulfate deposition also affects $\mathrm{Hg}$ in fish [8], because sulfate availability enhances $\mathrm{Hg}$ methylation by sulfate-reducing bacteria [8]. Landscapes can also vary in their sensitivity to $\mathrm{Hg}$ deposition [4,5]. Mercury-sensitive landscapes are those in which relatively small inputs of total $\mathrm{Hg}$ can cause significant contamination of fish in upper trophic levels [4,6]. Mercury sensitivity of landscapes is determined in part by land cover type. Some land cover types, such as forests and wetlands,

All Supplemental Data may be found in the online version of this article.

* To whom correspondence may be addressed (r.drenner@tcu.edu).

Published online 3 June 2011 in Wiley Online Library

(wileyonlinelibrary.com). promote $\mathrm{Hg}$ contamination of food webs, whereas other land cover types, such as agricultural areas, reduce $\mathrm{Hg}$ contamination of food webs [4].

Most of the research leading to the conceptual model predicting spatial patterns of $\mathrm{Hg}$ contamination of food webs has been conducted in the northeastern United States [5], but applicability of this model to other areas of the country has not been tested. North Texas is an ideal area for testing this conceptual model because of the extreme west-to-east gradients of deposition of atmospheric $\mathrm{Hg}$ and sulfate pollution and land cover types associated with $\mathrm{Hg}$ sensitivity (Fig. 1). Because ecoregions denote areas of general similarity in land cover types [9], we used ecoregion as the unit of analysis for the present study. Here we show that the ecoregion with the highest level of $\mathrm{Hg}$ contamination in fish is the South Central Plains, an $\mathrm{Hg}$ sensitive landscape that receives high levels of $\mathrm{Hg}$ and sulfate deposition. The present study has important implications for other areas of the United States, because the South Central Plains extend into parts of Oklahoma, Louisiana, and Arkansas, covering a total area of $152,132 \mathrm{~km}^{2}$ of the southern United States.

\section{MATERIALS AND METHODS}

We focused on largemouth bass (Micropterus salmoides) because it is widely distributed [10] and is an economically important species of freshwater game fish that is commonly included in fish tissue contaminant databases [7,11]. As adults, largemouth bass are piscivorous top predators, often having high $\mathrm{Hg}$ concentrations relative to other fish species [12]. We used a data set of 2,803 largemouth bass collected from 145 reservoirs in Texas (Supplemental Data, Table S1). Relative to other types of aquatic systems, reservoirs can have biota with elevated $\mathrm{Hg}$ concentrations [11].

Forty-five percent of the largemouth bass (1,265 fish) were collected by biologists from the Texas Parks and Wildlife 

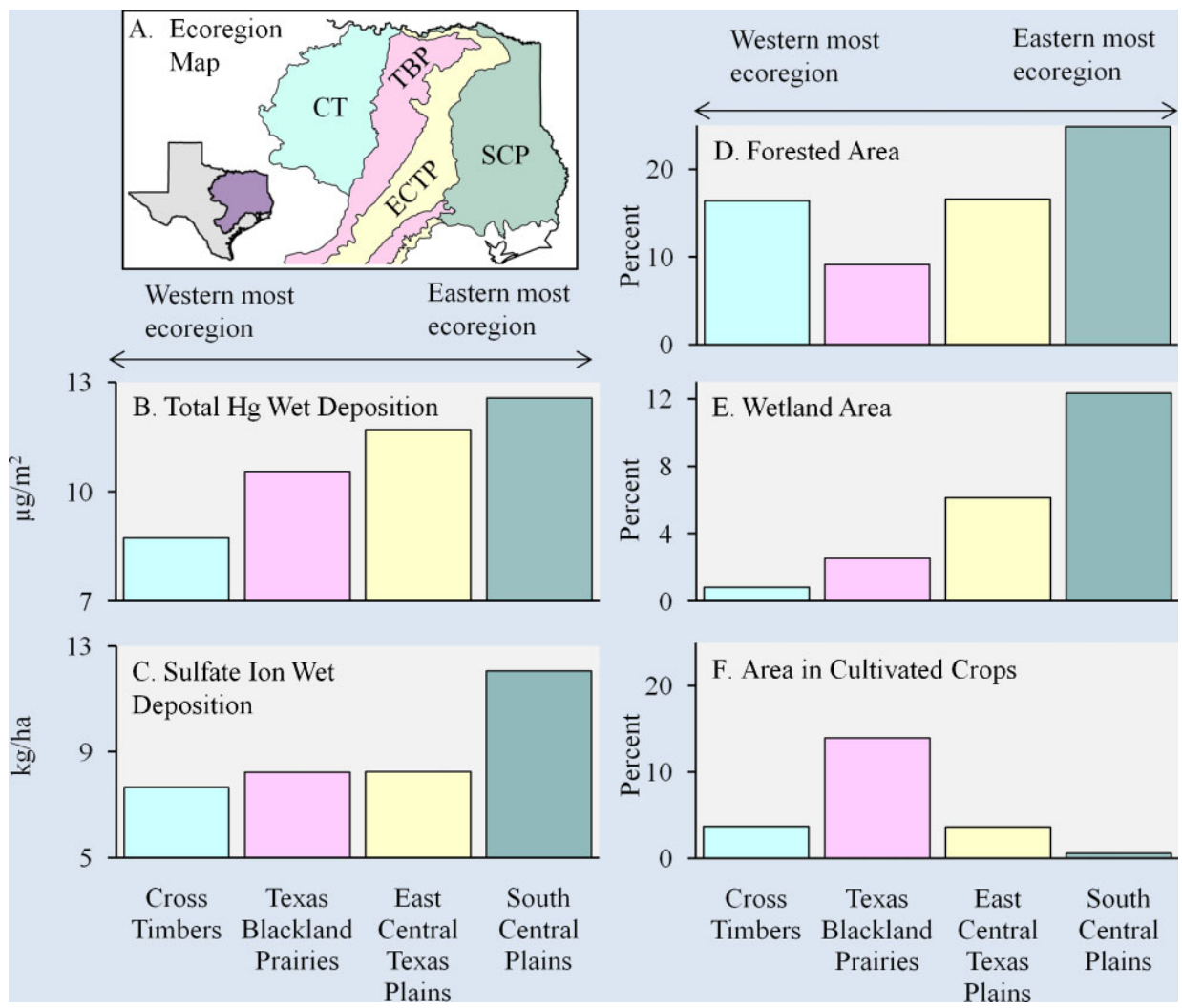

Fig. 1. (A) Map showing four U.S. Environmental Protection Agency level III ecoregions: Cross Timbers (CT), Texas Blackland Prairies (TBP), East Central Texas Plains (ECTP), and South Central Plains (SCP). Total Hg wet deposition (B) and sulfate ion wet deposition (C) in 2008 in the four ecoregions (http://nadp.sws.uiuc.edu). Percentage coverage by forested area (D), wetland (E), and cultivated crops (F) in 2001 (http://www.epa.gov/mrlc/nlcd-2001.html) in the four ecoregions. [Color figure can be seen in the online version of this article, available at wileyonlinelibrary.com]

Department (TPWD) during annual electrofishing surveys from 2004 to 2008 (Supplemental Data, Table S1) and analyzed for $\mathrm{Hg}$ concentrations in our laboratory. Fish were placed on ice in the field and later frozen for subsequent $\mathrm{Hg}$ analyses. Fillets were dissected from each fish, and a small subsample of epaxial muscle was collected from the center of each fillet for $\mathrm{Hg}$ analysis.

Total $\mathrm{Hg}$ concentrations were analyzed with a DMA-80 (Milestone) that uses thermal decomposition, gold amalgamation, and atomic absorption spectrometry [13]. We used total $\mathrm{Hg}$ as a proxy for $\mathrm{MeHg}$, because Bloom [14] estimated that $\mathrm{MeHg}$ accounted for $95 \%$ of the total $\mathrm{Hg}$ in several species of fish (including largemouth bass), and the U.S. Environmental Protection Agency (U.S. EPA) [15] recommends analyzing total $\mathrm{Hg}$ in fish tissues as a proxy for $\mathrm{MeHg}$. All $\mathrm{Hg}$ concentrations in the present study are total $\mathrm{Hg}$ and are reported as nanograms per gram wet wt. Detailed information about reference materials and quality assurance is supplied in the Supplemental Data.

Mercury concentration data for $55 \%$ of the largemouth bass (1,538 fish) were obtained from a published report [16], paper [17], federal database [18], and state databases, including the Texas Commission on Environmental Quality (TCEQ) database (P. Bohannon, TCEQ, personal communication), the Texas Department of State Health Services (TDSHS) database (K. Wiles, TDSHS, personal communication), and the TPWD database (R. Mills, TPWD, personal communication). These fish were collected between 1985 and 2009 (Supplemental Data, Table S1). All data were from analyses of $\mathrm{Hg}$ in skinless fillets of largemouth bass. Eighty-nine percent of samples were from individual fish, and $11 \%$ of the samples were composite samples of two to five largemouth bass. Although most states and several federal agencies routinely analyze $\mathrm{Hg}$ concentrations in fish, few studies have combined and evaluated these independently collected data sets $[5,7,11]$. In the present study, we used such data for the assessment of spatial patterns of $\mathrm{Hg}$ contamination of fish in North Texas.

Because fish $\mathrm{Hg}$ concentrations vary with length and it is difficult to obtain fish of a consistent length from all sites sampled, we used the National Descriptive Model of Mercury in Fish [19] to estimate the concentration of $\mathrm{Hg}$ in 46-cm-totallength (TL) largemouth bass by location and year for each reservoir. Forty-six-centimeters-TL is the largest largemouth bass commonly found in the creel in Texas (B. Farquhar, TPWD, personal communication). For reservoirs in which largemouth bass were collected in more than one year, we averaged predicted fish $\mathrm{Hg}$ concentrations for all years sampled to create a single value. Additional information about the National Descriptive Model of Mercury in Fish is given in the Supplemental Data.

Reservoirs sampled for largemouth bass were located using latitude and longitude coordinates and spatially mapped within ecoregions using ArcMap 9.3.1 software (Environmental Systems Research Institute). The Texas Statewide Mapping System (Lambert conformal conic projection) was used to project the data.

We examined spatial patterns of $\mathrm{Hg}$ in largemouth bass in four of the U.S. EPA level III ecoregions of Texas (Fig. 1), an area with a total surface area of $283,957 \mathrm{~km}^{2}$ [9]. Ecoregions provide a pragmatic way to investigate $\mathrm{Hg}$ accumulation in fish, especially when site-specific data are not available [20]. Ecoregions denote areas of general similarity in ecosystems and in the type, quality, and quantity of environmental resources [9]. 
They are designed to serve as a spatial framework for the research, assessment, management, and monitoring of ecosystems and ecosystem components [9]. We tested for ecoregion differences in mean $\mathrm{Hg}$ concentrations of largemouth bass in four ecoregions in North Texas. We used univariate ANOVA followed by the Games-Howell post hoc test (SPSS version 11.5.0) to test for differences in the mean $\mathrm{Hg}$ concentrations of largemouth bass in water bodies from the four ecoregions. Statistical significance was determined at $p<0.05$ for all analyses.

\section{RESULTS AND DISCUSSION}

\section{Spatial patterns of $\mathrm{Hg}$ contamination}

Mercury contamination varied with ecoregion (Fig. 2); the lowest and highest concentrations of $\mathrm{Hg}$ were in the Texas Blackland Prairies and South Central Plains, respectively (Fig. 3). The mean concentrations of $\mathrm{Hg}$ were significantly different between ecoregions (ANOVA, $d f=3,141, F=8.43$, $p<0.001$; Fig. 3). The mean concentration of $\mathrm{Hg}$ in the South Central Plains was $490 \mathrm{ng} / \mathrm{g}$, which was significantly greater than the East Central Texas Plains (297 ng/g; Games-Howell, $p=0.002)$, Texas Blackland Prairies (260 ng/g; GamesHowell, $p<0.001$ ), and Cross Timbers (304 ng/g; GamesHowell, $p=0.004)$. These results are consistent with the conceptual model predicting that highest $\mathrm{Hg}$ concentrations in fish would be located in areas with high deposition of $\mathrm{Hg}$ and sulfate combined with $\mathrm{Hg}$-sensitive landscapes.

It is important to recognize that the conceptual model predicts the potential for $\mathrm{Hg}$ contamination in fish in a

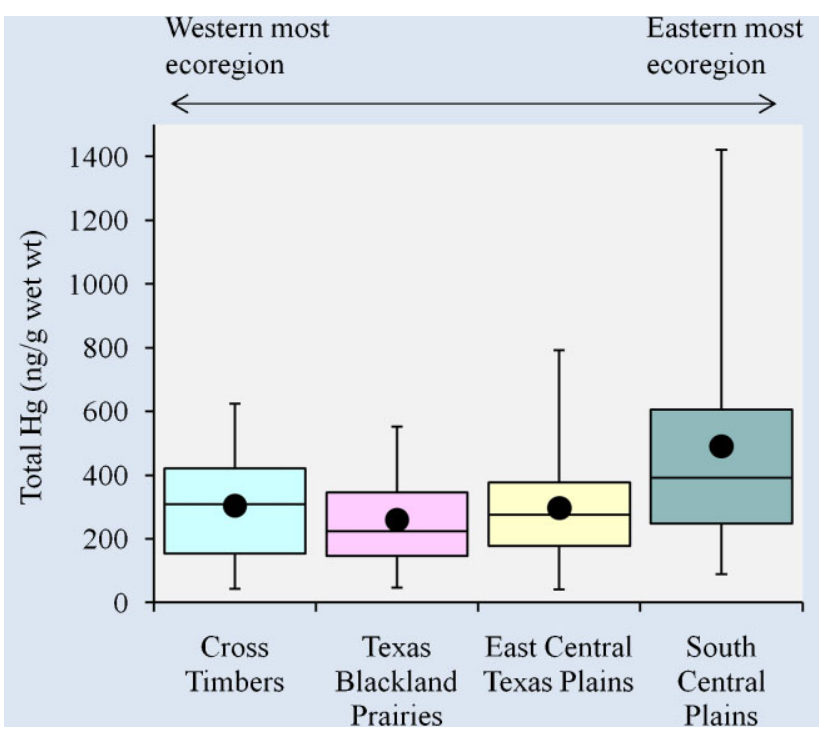

Fig. 3. Total Hg concentrations in largemouth bass from four ecoregions of North Texas, USA. Boxes, whiskers, horizontal lines, and points signify the first and third quartile, range, median and mean total $\mathrm{Hg}$ concentration of each ecoregion, respectively. [Color figure can be seen in the online version of this article, available at wileyonlinelibrary.com]

geographic area, but the contamination levels in individual reservoirs in an ecoregion would be expected to vary. We would expect, based on the model, a lower mean Hg concentration and smaller range of $\mathrm{Hg}$ concentrations in regions with low rates of $\mathrm{Hg}$ and sulfate deposition, low levels of forests and

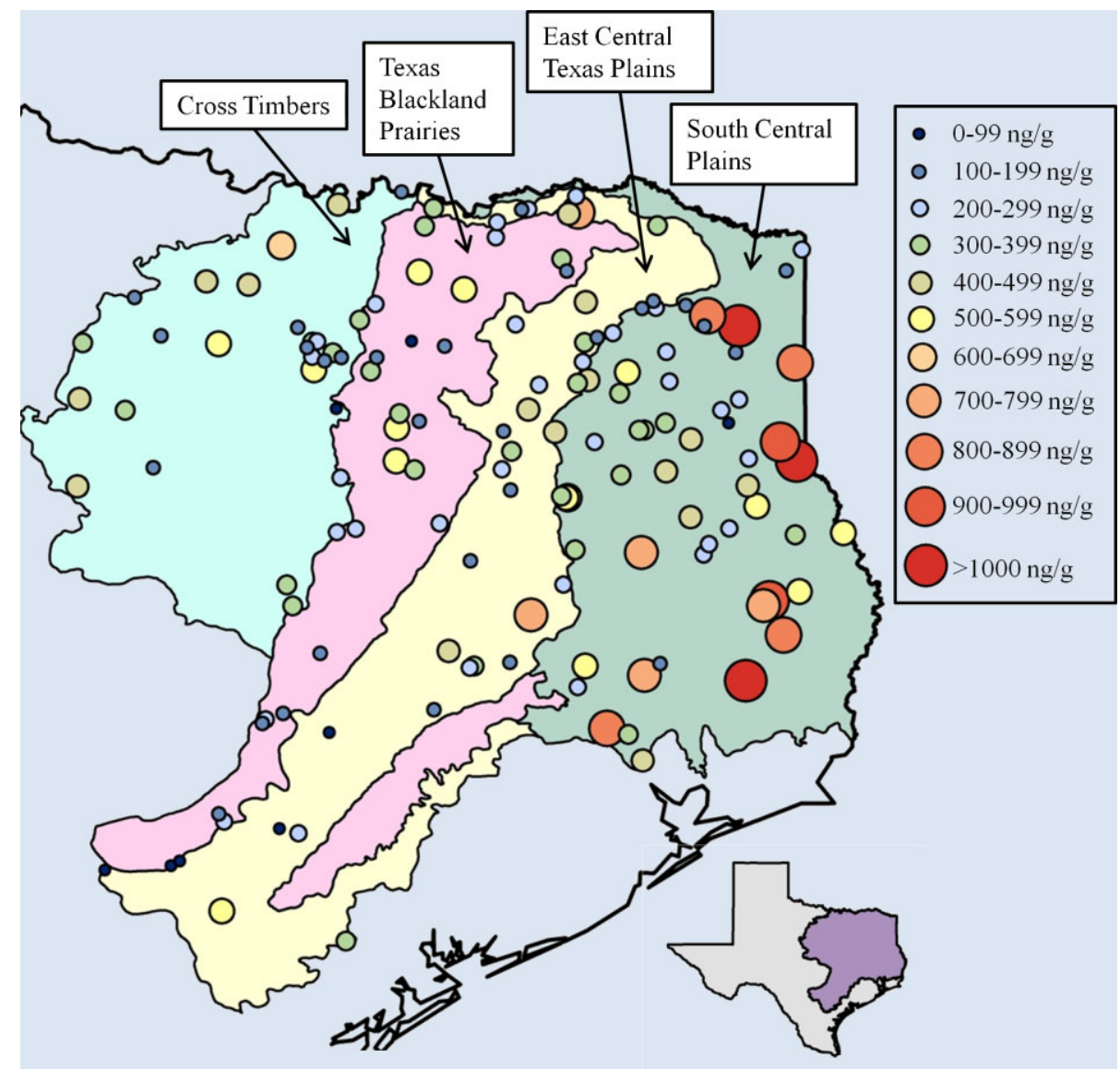

Fig. 2. Estimated total $\mathrm{Hg}$ concentrations in 46-cm-total-length largemouth bass from reservoirs in four ecoregions of North Texas, USA. [Color figure can be seen in the online version of this article, available at wileyonlinelibrary.com] 
wetlands, and high levels of agriculture [4,5]. Conversely, we would expect a higher mean $\mathrm{Hg}$ concentration and greater range of $\mathrm{Hg}$ in regions with high rates of $\mathrm{Hg}$ and sulfate deposition, high levels of forests and wetlands, and low levels of agriculture $[4,5]$. The difference in means and ranges between ecoregions in the present study (Fig. 3) is consistent with the predictions of the conceptual model.

We found that water bodies in close proximity to one another could have different $\mathrm{Hg}$ concentrations in largemouth bass (Fig. 2), a result consistent with other studies of spatial patterns of $\mathrm{Hg}$ in fish $[11,20]$. The $\mathrm{Hg}$ concentrations of fish in neighboring lakes can vary by as much as tenfold, even when atmospheric $\mathrm{Hg}$ deposition is similar [21]. Although the potential for $\mathrm{Hg}$ contamination is set by atmospheric pollution and $\mathrm{Hg}$ sensitivity, it does not result in all lakes in the region having high $\mathrm{Hg}$ contamination of the food webs, because many other factors, working at a local scale, determine the $\mathrm{Hg}$ of individual water bodies $[6,22]$. For example, other studies have found that variables such as $\mathrm{pH}$, dissolved organic carbon, and total phosphorus can account for variation in $\mathrm{Hg}$ contamination of biota between lakes $[4,20,23,24]$. Such data are not available for most of the Texas reservoirs considered in the present study, and understanding the factors responsible for interlake variability of $\mathrm{Hg}$ in a region was beyond the scope of the present study.

\section{Fish consumption advisories}

Fish consumption advisories are a widely used management tool to reduce the risk of adverse health effects in humans caused by consumption of $\mathrm{Hg}$-contaminated fish, while avoiding potentially large costs associated with reduction of the contaminant in the environment [25]. The TDSHS considers issuing fish consumption advisories when $\mathrm{Hg}$ concentrations in fish exceed a screening value of $700 \mathrm{ng} / \mathrm{g}$, but the U.S. EPA recommends that states use a screening value of $300 \mathrm{ng} / \mathrm{g}$ [26]. The TDSHS has issued fish consumption advisories for concentrations of $\mathrm{Hg}$ in fish above $700 \mathrm{ng} / \mathrm{g}$ for 12 reservoirs in North Texas. The present study suggests that use of the U.S. EPA screening value would result in a significant increase in the number of reservoirs with fish consumption advisories for $\mathrm{Hg}$. Fifty-one percent of reservoirs had largemouth bass above the U.S. EPA screening value of $300 \mathrm{ng} / \mathrm{g}$, and only $10 \%$ of reservoirs had largemouth bass above the TDSHS screening value of $700 \mathrm{ng} / \mathrm{g}$ (Fig. 4A). Only reservoirs in the East Central Texas Plains and the South Central Plains had 46-cm-TL largemouth bass above the TDSHS advisory level, but all four ecoregions have a significant percentage of reservoirs with largemouth bass above the U.S. EPA screening value (Fig. 4B).

Consumption advisories can be ineffective in protecting humans and wildlife. Angler compliance with fish advisories can be low, and anglers continue to consume contaminated fish from water bodies with advisories [27]. Advisories would not cover the small private ponds that are not monitored by the state, but these ponds numerically dominate the landscape [28] and may have high levels of $\mathrm{Hg}$ contamination [29]. Moreover, advisories would not protect fish and wildlife that consume $\mathrm{Hg}$ contaminated prey and suffer $\mathrm{Hg}$-related health consequences [30,31]. The results of the present study are consistent with the emerging conceptual model and, consequently, indicate that a reduction in atmospheric $\mathrm{Hg}$ and sulfate loading would help to reduce fish $\mathrm{Hg}$ burdens in Texas. Mercury being deposited in this area is coming from the global $\mathrm{Hg}$ pool and North American sources [32], but the relative contribution of these sources to water bodies in Texas is unknown.

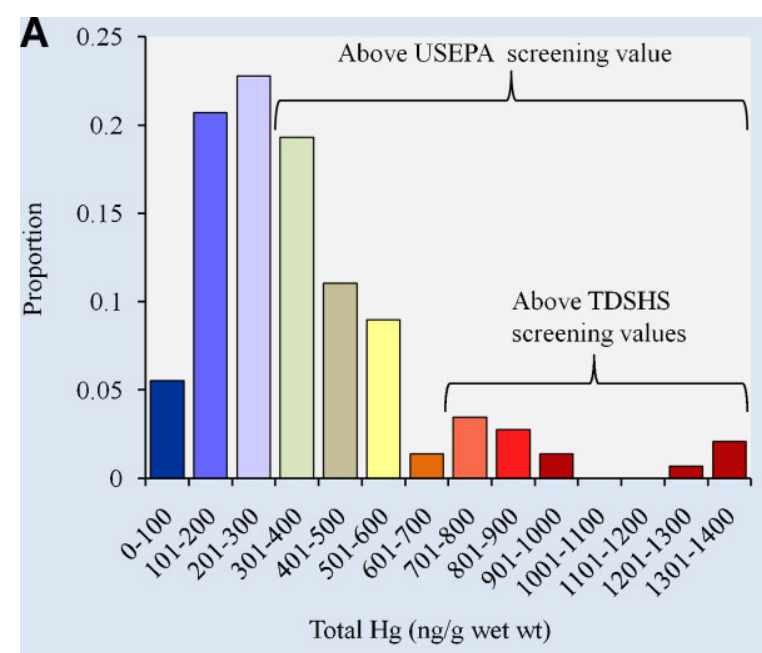

B

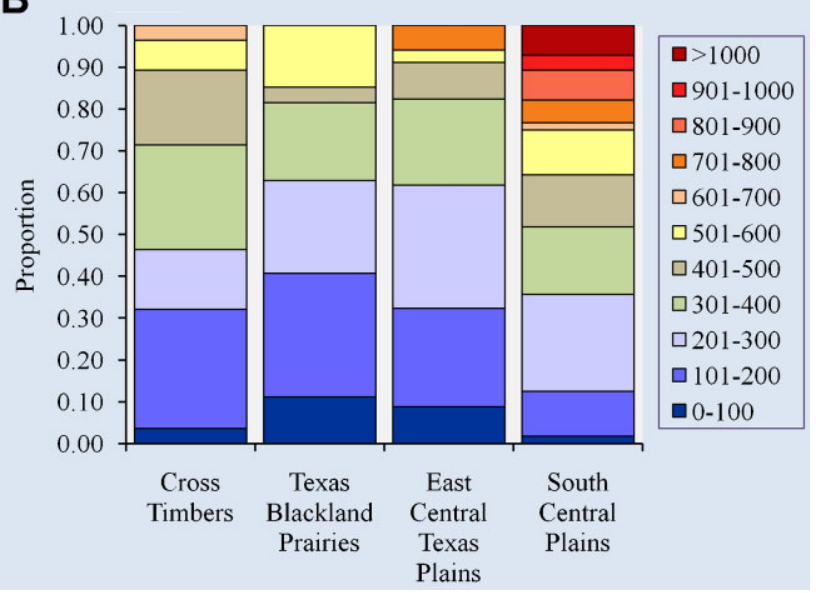

Fig. 4. (A) Proportion of 46-cm-total-length largemouth bass having estimated total $\mathrm{Hg}$ concentrations from 0 to $1,400 \mathrm{ng} / \mathrm{g}$. Proportion of fish with $\mathrm{Hg}$ concentrations exceeding U.S. Environmental Protection Agency and Texas Department of State Health Services screening values (the benchmarks used by the two organizations to issue fish consumptions advisories) are indicated by brackets. (B) Proportion of 46-cm-total-length largemouth bass in $100 \mathrm{ng} / \mathrm{g}$ categories in the four ecoregions of North Texas. [Color figure can be seen in the online version of this article, available at wileyonlinelibrary.com]

\section{CONCLUSIONS}

We have shown that some reservoirs in the South Central Plains in East Texas are highly contaminated with $\mathrm{Hg}$. This ecoregion receives high rates of wet $\mathrm{Hg}$ and sulfate deposition (http://nadp.sws.uiuc.edu) and is $\mathrm{Hg}$-sensitive because of its forests, wetlands, and low levels of agricultural vegetation. The present study has implications beyond Texas, because the South Central Plains extends across parts of Oklahoma, Arkansas, and Louisiana, covering a total area of $152,132 \mathrm{~km}^{2}$. Like Texas, these three states also receive relatively high rates of wet $\mathrm{Hg}$ and sulfate deposition (http://nadp.sws.uiuc.edu). If the other areas of the South Central Plains ecoregion are as contaminated as the Texas portion, this ecoregion would be one of the largest geographic areas with highly $\mathrm{Hg}$-polluted water bodies yet identified in the United States.

\section{SUPPLEMENTAL DATA}

Table S1. Data sources used in the present study (48 KB XLS) 
Fig. S1. Predicted fish-mercury concentrations as a function of length for skin-off fillet cuts of 11 frequently sampled species (102 KB DOC).

Acknowledgement-We are grateful to inland fisheries biologists from the TPWD for donating largemouth bass to the present study. Shannon Andrew, Niki Long, Peter Mitchell, Kim Nguyen, and Genesis Sultemeir provided assistance in the laboratory. We thank Pat Bohannon, Roxie Mills, and Kirk Wiles for access to TCEQ, TPWD, and TDSHS databases, respectively. Bobby Farquhar provided information about creel census data from TPWD, and Tamie Morgan assisted with Geographic Information System analyses. Financial support was provided by NextEra Energy Resources, the Texas Christian University Research and Creative Activities Fund, and the Caddo Lake Institute.

\section{REFERENCES}

1. National Research Council. 2000. Toxicological Effects of Methylmercury. National Academy, Washington DC.

2. Mergler D, Anderson HA, Chan LHM, Mahaffey KR, Murray M, Sakamoto M, Stern AH. 2007. Methylmercury exposure and health effects in humans: A worldwide concern. Ambio 36:3-11.

3. U.S. Environmental Protection Agency. 2009. 2008 Biennial national listing of fish advisories. EPA-823-F-09-007. Washington, DC.

4. Driscoll CT, Han Y, Chen CY, Evers DC, Lambert KF, Holsen TM, Kamman NC, Munson RK. 2007. Mercury contamination in forest and freshwater ecosystems in the northeastern United States. BioScience 57:17-28.

5. Evers DC, Han Y, Driscoll CT, Kamman NC, Goodale MW, Lambert KF, Holsen TM, Chen CY, Clair TA, Butler T. 2007. Biological mercury hotspots in the northeastern United States and southeastern Canada. BioScience 57:29-43.

6. Wiener JG, Krabbenhoft DP, Heinz GH, Scheuhammer AM. 2003. Ecotoxicology of mercury. In Hoffman DJ, Rattner BA, Burton GA Jr, Cairns J Jr, eds, Handbook of Ecotoxicology, 2nd ed. Lewis, Boca Raton, FL, USA.

7. Hammerschmidt CR, Fitzgerald WF. 2006. Methylmercury in freshwater fish linked to atmospheric mercury deposition. Environ Sci Technol 40:7764-7770.

8. Drevnick PE, Canfield DE, Gorski PR, Shinneman ALC, Engstrom DR, Muir DCG, Smith GR, Garrison PJ, Cleckner LB, Hurley JP, Noble RB, Otter RR, Oris JT. 2007. Deposition and cycling of sulfur controls mercury accumulation in Isle Royale fish. Environ Sci Technol 41:7266-7272.

9. Griffith GE, Bryce SA, Omernik JM, Comstock JA, Rogers AC, Harrison B, Hatch SL, Bezanson D. 2004. Ecoregions of Texas. U.S. Geological Survey, Reston, VA.

10. Thomas C, Bonner TH, Whiteside BG. 2007. Freshwater Fishes of Texas: A Field Guide. Texas A\&M, College Station, TX, USA.

11. Kamman NC, Burgess NM, Driscoll CT, Simonin HA, Goodale W, Linehan J, Estabrook R, Hutcheson M, Major A, Scheuhammer AM, Scruton DA. 2005. Mercury in freshwater fish of northeast North America-A geographic perspective based on fish tissue monitoring databases. Ecotoxicology 14:163-180.

12. Chumchal MM, Hambright KD. 2009. Ecological factors regulating mercury contamination of fish from Caddo Lake, Texas, USA. Environ Toxicol Chem 28:962-972.
13. U.S. Environmental Protection Agency. 1998. Method 7473: Mercury in solids and solutions by thermal decomposition, amalgamation, and atomic absorption spectrophotometry. Washington, DC.

14. Bloom NS. 1992. On the chemical form of mercury in edible fish and marine invertebrate tissue. Can J Fish Aquat Sci 49:1010-1017.

15. U.S. Environmental Protection Agency. 2000. Guidance for assessing chemical contaminant data for use in fish advisories. EPA-823-B-00007. Washington, DC

16. Twidwell S. 2000. Bioaccumulation of mercury in selected east Texas water bodies. AS-180. Texas Commission on Environmental Quality, Austin, TX, USA.

17. Chumchal MM, Drenner RW, Fry B, Hambright KD, Newland LW. 2008. Habitat-specific differences in mercury concentration in a top predator from a shallow lake. Trans Am Fish Soc 137:195-208.

18. U.S. Environmental Protection Agency. 2009. National Lake Fish Tissue Study. EPA-823-R-09-006. Washington, DC, USA.

19. Wente SP. 2004. A statistical model and national data set for partitioning fish-tissue mercury concentration variation between spatiotemporal and sample characteristic effects. Scientific Investigation Report 2004 5199. U.S. Geological Survey, Reston, VA.

20. Sackett DK, Aday DD, Rice JA, Cope WG. 2009. A statewide assessment of mercury dynamics in North Carolina water bodies and fish. Trans Am Fish Soc 138:1328-1341.

21. Swain EB, Jakus PM, Rice G, Lupi F, Maxson PA, Pacyna JM, Penn A, Spiegel SJ, Veiga MM. 2007. Socioeconomic consequences of mercury use and pollution. Ambio 36:45-61.

22. Munthe J, Bodaly RA, Branfireun BA, Driscoll CT, Gilmour CC, Harris R, Horvat M, Lucotte M, Malm O. 2007. Recovery of mercurycontaminated fisheries. Ambio 36:33-44.

23. Lange TR, Royals HE, Connor LL. 1993. Influence of water chemistry on mercury concentration in largemouth bass from Florida lakes. Trans Am Fish Soc 122:74-84.

24. Hanten RP, Neumann RM, Ward SM. 1998. Relationships between concentrations of mercury in largemouth bass and physical and chemical characteristics of Connecticut lakes. Trans Am Fish Soc 127:807-818.

25. Jakus PM, Dadakas D, Fly JM. 1998. Fish consumption advisories: Incorporating angler-specific knowledge, habits, and catch rates in a site choice model. Am J Agric Econ 80:1019-1024.

26. U.S. Environmental Protection Agency. 2001. Mercury update: Impact on fish advisories. EPA-823-F-01-011. Washington, DC.

27. Jakus P, Downing M, Bevelhimer M, Fly M. 1997. Do sportfish consumption advisories affect reservoir anglers' site choice? Agric Res Econ Rev 26:196-204.

28. Smith SV, Renwick WH, Bartley JD, Buddemeier RW. 2002. Distribution and significance of small, artificial water bodies across the United States landscape. Sci Total Environ 299:21-36.

29. Blackwell BD, Drenner RW. 2009. Mercury contamination of macroinvertebrates in fishless grassland ponds. Southwest Nat 54:468-474.

30. Wolfe MF, Schwarzbach S, Sulaiman RA. 1998. Effects of mercury on wildlife: A comprehensive review. Environ Toxicol Chem 17:146-160.

31. Scheuhammer AM, Meyer MW, Sandheinrich MB, Murray MW. 2007. Effects of environmental methylmercury on the health of wild birds, mammals, and fish. Ambio 36:12-18.

32. Selin NE, Jacob DJ. 2008. Seasonal and spatial patterns of mercury wet deposition in the United States: Constraints on the contribution from North American anthropogenic sources. Atmos Environ 42:51935204. 